\title{
Tobit Analysis of Factors Influencing Loan Repayment Performance: A Case Study of Lift Above Poverty Organization (LAPO) Micro-Credit Agency in Nigeria
}

\author{
Olatomide Waheed Olowa, Omowumi Ayodele Olowa \\ Department of Agricultural Education, Federal College of Education (Technical) Akoka, Lagos, Nigeria
}

Email address:

Olowa1@yahoo.com (O. A. Olowa)

To cite this article:

Olatomide Waheed Olowa, Omowumi Ayodele Olowa. Tobit Analysis of Factors Influencing Loan Repayment Performance: A Case Study of Lift Above Poverty Organization (LAPO) Micro-Credit Agency in Nigeria. Mathematics Letters. Vol. 3, No. 6, 2017 , pp. 58-64.

doi: $10.11648 /$ j.ml.20170306.11

Received: January 28, 2017; Accepted: February 13, 2017; Published: November 13, 2017

\begin{abstract}
The Microfinance system in Nigeria and many sub-Sahara countries has suffered serious setback due to poor loan repayment. This study attempt at assessing the loan-repayment performance of Lift Above Poverty Organization (LAPO). LAPO in Nigeria was chosen to be investigated because of its profile of attaining one million borrowers and disbursement of one billion dollars in micro-credits to smallholders. Secondary data on LAPO micro-credits from different sources from 1990 to 2014 were analyzed using Simple descriptive statistics such as percentages, mean, t-tests and regression techniques. The results of the analyses showed at 0.92 repayment rate and 0.08 default rate, LAPO enjoys high level of repayment and a low default rate. As further shown by the results, this is spurred by the borrower experience, positive effects of the volume of loans borrowed, number of borrowers, number of credit agency staff, and volume of loans repaid. Incentive-driven system and further administrative re-engineering towards enhancing repayment performance is recommended.
\end{abstract}

Keywords: LAPO Microfinance, Micro Credit Repayment Performance, Repayment Rate, Default Rate, Nigeria

\section{Introduction}

Micro finance/credit emanated from efforts to reduce poverty, promote income inequality and rural community development designed to encourage financial inclusiveness. The evolution of current Micro Finance Institution (MFI) can be traced back to the development of a wide range of institutions and movements that shared the aim of expanding financial services to the poor. The "poverty-lending" approaches emphasize the reduction of poverty through the provision of financial services to the very poor as a means of personal empowerment [24]. Micro finance, a system of providing small loans to those who are excluded from normal banking institutions, is seen by many as one way to help the poor increase their income and productivity [9]. The concept of micro finance has emerged as a potential solution to the financial insecurity of the economically disadvantaged since the early 1970s. Arising from the successes of the Grameen Bank, new generation of credit providers brought the concept of micro finance to the forefront of poverty alleviation, providing relatively small loans to low resource individuals and families [8]. In recognition of this concept, the United Nations adopted Resolution 53/197 in which it proclaimed 2005 as the International Year of Micro Credit and requested that the observance of the year be a special occasion for giving impetus to micro credit programs throughout the world [27]. Micro financing entails granting loans which are usually 'micro' in quantum with bounding commitment from the borrower to repay back with minimum interest far less to what is obtainable at the commercial banks. The interest charged on the principal serves to offset administrative and supervisory cost incurred on the fund by the lending institutions and to make overages for profit. Poor loan repayment has become very critical among MFIs. This problem has negatively affected producers/traders who need to obtain capital for their operations [18]. Several studies investigated the importance of the credit facilities in less-developed countries. These studies concentrate on the effects of providing a large amount of money in the form of agricultural loans on the agricultural sector growth $[10,1,22]$, with less emphasis on loan 
repayment. Micro finance activities in many developing countries suffer from the problem of a high incidence of default rate among borrowers. Many of these micro-credit agencies are inefficient or heavily subsidized to remain in business. In order to understand the reasons behind this problem, it is crucial to evaluate the Lift above Poverty organization based on borrowers' repayment performance. It is important to accomplish this evaluation because a low repayment rate will reduce the volume of loanable funds to offer other borrowers, create a longer time for loan recovery and lower profitability [3]. Loan-repayment performance is largely affected by factors related to the borrower, the firm itself, the loan, and the lender. Among these factors, many studies concentrate on the borrower as the core of the problem. Most of these studies stated that, when the loan is not paid, it might be a result of the borrowers' unwillingness and/or inability to repay $[11,12,6$, and 21$]$.

Borrower's unwillingness or inability to pay may evolve from unstable prices of agricultural inputs and outputs, interest rates, and the borrowers' social relations and responsibilities. The negative effect of these factors may lead to the failure of these agencies. Accordingly, lending agencies categorizes the borrowers as good borrowers and bad borrowers. Monitoring the borrowers will aid in making sure that loans are utilized for the right purposes meaning that they can pay back their loans [25]. Looking at the borrowers' past record is another criterion to determine if the borrower is likely to repay the loan or not [11]. Borrowers with no training related to their agribusiness have a higher possibility to default [23]. The lending firm characteristics may also affect their repayment performance. [20, 17, 4]. A firm's Poor management procedures may also contribute to most of the default. The design of the loan, access methods, screening methods, and incentives to repay may largely affect the lending agencies repayment performance [13]. The loan volume may be another issue to discuss. Awoyemi and Olowa [3] stated that the larger the loan size, the lower the probability of repayment default. A Poorly designed lending program and improper implementation may lead to defaults [5]. To minimize the loan default in the process loan repayment, both the borrowers and the institutional characteristics are important and should be taken into account [7].

In Nigeria, the Lift Above Poverty Organization (LAPO) is a major micro finance institution. It was incorporated as a company limited by guarantee (non-profit) under the Companies and Allied Matter Act (1990). Traders/smallholders clients are its main target group. The total value of the loans provided to clients through this cooperation by the end of 2014 was nearly $\$ 1$ billion dollar, which is around $\mathrm{N} 350 \mathrm{~B}$; ( $\mathrm{N50}=1 \mathrm{USD}$ ) and benefited nearly $1,000,000$ customers [15]. The quantum of the credit benefitted by LAPO customers has increased in recent years, but the number of loans declined. Perhaps it is an indication of spreading the loan marketing net while swiftly dealing with defaulters. An efficient utilization of Lift above Poverty organization credit also mean prompt repayment.

The present study is an attempt to assess the repayment performance of the borrowers using LAPO as a case study. Hence, the study investigated some important factors related to loan repayment performance drawing from the LAPO's experience and making appropriate recommendations to inform policies.

\section{Methodology}

\subsection{Data}

To achieve the objective of this study which is assessing the repayment performance of micro finance institution using LAPO's customers as case study, Secondary data from various sources including the official website of the Microfinance, Information Exchange Incorporated, USA were used. The relative ease of availability and accessibility of required data from secondary sources over a long period of about 14 years underpinned choice of type of data. Data used in the study included volume of loans borrowed, volume of loans repaid, number of borrowers, number of credit agency staff/client.

Table 1 shows the main credit related items of the LAPO between 2012 and 2014. Loans are in US Dollar. ( $\$ 350=1$ USD).

Table 1. Main credit-related items of the LAPO (2012-2014).

\begin{tabular}{llll}
\hline Period type & ANN & ANN & ANN \\
\hline As of date & $12 / 31 / 2012$ & $12 / 31 / 2013$ & $12 / 31 / 2014$ \\
+ Number of active borrowers & 559,227 & 685,138 & 800,611 \\
Percent of female borrowers & $92.51 \%$ & $92.82 \%$ & $90.11 \%$ \\
+ Number of loans outstanding & 559,227 & 685,138 & 800,611 \\
+ Gross Loan Portfolio & $108,410,676$ & $146,515,411$ & $181,198,493$ \\
Cumulative loans disbursed & & & \\
Average loan balance per borrower / GNI per capita & $13.84 \%$ & $15.26 \%$ & $21,114.33 \%$ \\
Average loan balance per female borrower & & $0.00 \%$ & 226 \\
Average outstanding balance & 194 & 214 & $1,414,964$ \\
Average outstanding balance / GNI per capita & $13.84 \%$ & $15.26 \%$ & $1,414,964$ \\
+ Number of depositors & 756,904 & $1,038,340$ & $110,931,334$ \\
+ Number of deposit accounts & 756,904 & $1,038,340$ & 78 \\
+ Deposits & $62,715,664$ & $86,611,729$ & 78 \\
Average deposit balance per depositor & 83 & 83 & \\
Average deposit balance per depositor / GNI per capita & $6.00 \%$ & $6.00 \%$ & 73 \\
Average deposit account balance & 83 & 83 & \\
\hline
\end{tabular}

Source: Information Exchange Incorporated, USA 
Table 2. Volume of Loan Borrowed and Repaid (1991-2014).

\begin{tabular}{lll}
\hline Year & Volume of loan Borrowed & Volume of loan repaid \\
\hline 1991 & 1052766 & 1040431 \\
1992 & 3238850 & 3105174 \\
1993 & 18909314 & 12010890 \\
1994 & 14307265 & 12337558 \\
1995 & 19345227 & 15236697 \\
1996 & 21188319 & 18242230 \\
1997 & 16797331 & 19876409 \\
1998 & 19680900 & 18726206 \\
1999 & 27368944 & 22978324 \\
2000 & 20891375 & 24667207 \\
2001 & 13376951 & 20737899 \\
2002 & 17199522 & 19452318 \\
2003 & 13206155 & 12151404 \\
2004 & 10991096 & 80196712 \\
2005 & 16266946 & 15258937 \\
2006 & 19387065 & 27800000 \\
2007 & 20777039 & 27123474 \\
2008 & 25488470 & 32168543 \\
2009 & 24930487 & 26385876 \\
2010 & 24082721 & 27600000 \\
2011 & 38613085 & 30800000 \\
2012 & 10817600 & - \\
2013 & $146,155,000$ & - \\
2014 & $1000,081,158$ & - \\
\hline
\end{tabular}

Source: LAPO Website and Information Exchange Incorporated, USA

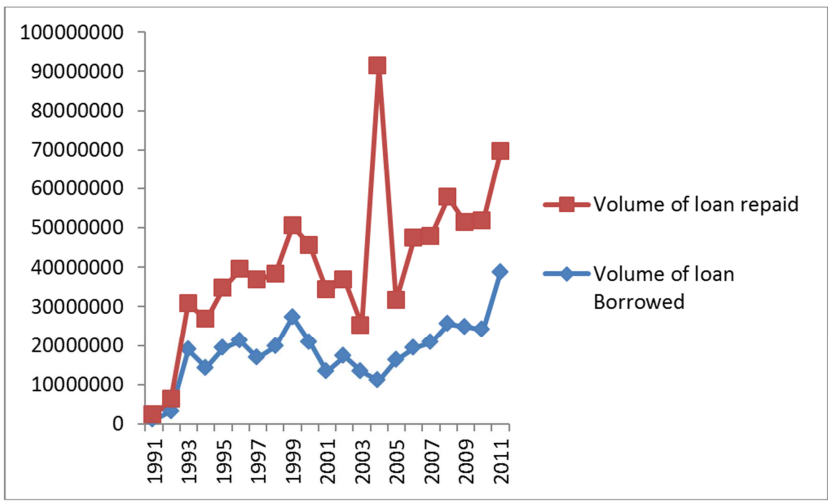

Figure 1. Trend analysis of Loan and Repaid.

\subsection{Analytical Framework}

Descriptive statistics such as mean and standard deviation were used to summarise the data while Tobit regression analysis was used to determine factors that are related to micro credit repayment rate with respect to LAPO. To test the differences between the mean volume of credit borrowed and the mean volume repaid, t-test was used.

\section{Tobit Regression}

In order to accomplish the objectives of this paper, the Tobit model was used to estimate the factors which influence the loan repayment performance of LAPO. The Tobit model, originally developed by Tobin [26], may be expressed in the following way: $Y^{*}=X \beta+\varepsilon$ where $\beta$ is a vector of unknown coefficients, $\mathrm{X}$ is a vector of independent variables, and $\varepsilon$ is an error term that is assumed to be independently distributed with mean zero and a variance of $\mathrm{s}^{2}$. $\mathrm{Y}^{*}$ is a latent variable that is unobservable. If data for the dependent variable is above the limiting factor, zero in this case, $\mathrm{Y}$ is observed as a continuous variable. If $\mathrm{Y}$ is at the limiting factor, it is held at zero. This relationship is presented mathematically in the following two equations:

$\mathrm{Y}=\mathrm{Y}^{*}$ if $\mathrm{Y}^{*}>\mathrm{Y} 0$; $\mathrm{Y}=0$ if $\mathrm{Y}^{*}<\mathrm{Y}_{0}$ where $\mathrm{Y}_{0}$ is the limiting factor. These two equations represent a censored distribution of the data. The Tobit model can be used to estimate the expected value of $\mathrm{Yi}$ as a function of a set of explanatory variables $(\mathrm{X})$ weighted by the probability that Yi $>0$

The regression model is specified explicitly as follows:

$$
Y=\beta_{0}+\beta_{1} X_{1}+\beta_{2} X_{2}+\ldots . .+\beta_{6} X_{6}+\varepsilon
$$

$\mathrm{Y}=$ repayment ratio (volume of repaid loans divided by the volume of loans given by the LAPO).

$\mathrm{B}_{0}=$ Intercept

$\mathrm{X}_{1}=$ volume of loans borrowed from LAPO.

$\mathrm{X}_{2}=$ volume of loans repaid to LAPO.

$\mathrm{X}_{3}=$ number of borrowers.

$\mathrm{X}_{4}=$ number of LAPO staff members.

$\mathrm{X}_{5}=$ borrower's age.

$\mathrm{X}_{6}=$ business experience of borrower.

$\mathrm{e}=$ error term.

$\beta_{1}, \beta_{2}, \ldots, \beta_{6}$ are regression parameters to be estimated.

The volume of loans borrowed from LAPO and the number of borrowers are variables related to client accessibility to credits offered by LAPO. The volume of loans repaid to LAPO is a variable related to LAPO collection performance. The dependent variable is the repayment rate (volume of repaid loans divided by the volume of loans given by LAPO).

\section{Results and Discussion}

The repayment performance of any MFI may be negatively affected by certain factors and thus hamper MFI performance. The result of analysis of factors that are strongly related to the repayment performance and the administrative performance using LAPO as case study are reported in the subsequent paragraph.

\subsection{Demographical Characteristics of Respondents}

The Demographical characteristics of LAPO's Clients are presented in Table 3.

Table 3. Demographics of LAPO's Clients.

\begin{tabular}{lll}
\hline Characteristics & Mean & Standard Deviation \\
\hline Age of farmers (Years) & 48 & 0.0865 \\
Household size & 6.09 & 0.0474 \\
Education (years) & 4.14 & 0.6740 \\
Business Experience (Years) & 20 & 0.9056 \\
\hline
\end{tabular}

Source: LAPO's various Report 
As table 3 shows, the average age of the borrowers was 48 years. The majority of borrowers were between 30 and 50 years old, age bracket considered to economically important in that it is the period of life individuals are highly productive and active to engage in work, and these borrowers do not have much education. On an average, they have only four years of education which indicates high levels of illiteracy among borrowers. The average size of the households of about 6 persons is an indication of large household. Large household size ensures availability of family labour but could also hamper repayment through burden of family upkeep. Although, this was not tested as secondary data did not provide the size of individual loan.

\subsection{Main Credit-Related Items}

As shown in Table 2, the volume of loans offered by the LAPO to the borrowers increased from $\$ 1052766$ borrowed by 4,242 clients in 1991 to about $\$ 146$ million dollar borrowed by 685,138 clients in 2013 and $\$ 1000,081,158$ borrowed by 1 million clients in 2014 . The increase in the quantum or volume of loans is about $98 \%$ while similar trend is observed in the increase in the number of borrowers for the same period. This indicates that on average, volume of loan per beneficiary was higher in the later operational years of LAPO when compared to the earlier times. Critically, the relative lower rate of increase in borrowers compared to the higher loans' volume is pertinent in determining the repayment performance of LAPO.

Table 4 shows the repayment rate, or the percentages of repaid loans to borrowed loans (R/B) since 1991 for LAPO. Critically, LAPO repayment rate from 1991-1996 was low relative to other periods. The repayment rate in other periods was higher. (> $100 \%$ in some instance). The difference in the two periods (1991-1996 and 2000-2011) could be attributed to the lack of consistency in the growth performance of Nigeria's agricultural sector and MSMEs from 1991-1996 as well as to instability and inconsistencies in agricultural policies, policy implication, and poor monitoring and management during other periods, except those after the year 2000 .

Table 4. Repayment rate (R/B), 1991-2014.

\begin{tabular}{llll}
\hline Year & R/B (\%) & Year & R/B (\%) \\
\hline & & 2001 & 155 \\
1991 & 62 & 2002 & 113 \\
1992 & 23 & 2003 & 168 \\
1993 & 64 & 2004 & 211 \\
1994 & 86 & 2005 & 161 \\
1995 & 79 & 2006 & 143 \\
1996 & 86 & 2007 & 131 \\
1997 & 98 & 2008 & 126 \\
1998 & 95 & 2009 & 106 \\
1999 & 84 & 2010 & 115 \\
2000 & 118 & 2011 & 108 \\
2012 & 84 & 2013 & 89 \\
2014 & 92 & & \\
Average=0.92 & & & \\
\hline
\end{tabular}

Source: Calculated by the researchers using data from the LAPO's annual reports and other sources.

The results further show that the average LAPO repayment rate is 0.92 (1991-2014), indicating good repayment performance, considering the fact that no MFI can have a $100 \%$ repayment rate.

This trend is observable in the figure 1. Concerning LAPO's administrative performance, on average, the volume of loans per staff member was $\$ 189$ and the number of borrowers per staff member was 341 (see Table 1). These figures when compared to MFIs in other developing countries indicate that the LAPO's administrative performance need to be up-scaled. The lower the two indicators are, the better the administrative performance that, in turn, reflects on the agency's repayment performance. Loan defaults arose from poor management or administrative procedures.

\subsection{T-test Analysis}

T-test was used to test the differences between the mean volume of credit borrowed and the mean volume repaid. The statistical difference between the mean values of loans obtained $\left(\mathrm{X}_{1}\right)$ and the mean amount of loans repaid $\left(\mathrm{X}_{2}\right)$ by borrowers is presented in Table 5 .

Table 5. The Mean Difference between the Volume of Loan and Repayment Rate.

\begin{tabular}{lllll}
\hline Variable Mean & Standard Deviation & Degrees of Freedom & t-value & Sig. (2-tailed) \\
\hline Volume borrowed & 9813540.4 & 9248949.8 & 517.651 & .000 \\
Volume repaid & 9967358.4 & 10354951.4 & 516.941 & .000 \\
\hline
\end{tabular}

Source: Author's Calculation.

The result reveals that at 5\% level, there was no significant difference between the mean volume or quantum of loans borrowed and the mean volume of loans repaid by borrowers. The implication of these results is that clients exhibited high loan-repayment performance that positively reflected in the credit agency's repayment performance. These results confirm the information presented in Table 4.

\subsection{Regression Model}

The results for the regression of factors that influence LAPO's loan repayment performance are presented in Table 5. Regression estimates showed that the volume of loans repaid, the number of staff members, and the borrowers' 
business experience prove to be significant at the $95 \%$ confidence level. The remaining three variables were not significant at that level. The outcome here pinpoint the importance of considering these variables when planning to analyze the repayment performance of LAPO. Other studies with comparable coefficient of determination include [2, 19].

The signs of the variables in the model conform to a priori expectation except for coefficient of borrowed loan $\left(\mathrm{X}_{1}\right)$ which against a priori expectation was positive. It was expected to have a negative sign. The positive sign for the coefficient of the volume of the repaid loan $\left(\mathrm{X}_{2}\right)$, the number of borrowers $\left(X_{3}\right)$, the numbers of staff members $\left(X_{4}\right)$, and borrowers' business experience $\left(\mathrm{X}_{6}\right)$ as well as the negative relationship for the coefficient of the borrower's age $\left(\mathrm{X}_{5}\right)$ with the repayment rate (Y) are in line with a prior expectations. The signs of the coefficient of independent variables and the significance of these variables are used to determine the impact of each independent variable on the dependent variable.

The results presented in Table 6 reveal that all the explanatory variables in the model have a positive effect on the repayment rate, and hence repayment performance, except the borrower's age which had a negative effect. Each $1 \%$ increase for the volume of loans borrowed from the LAPO, the volume of loans repaid to, including LAPO profits, the number of borrowers, the number of LAPO staff members, and the borrowers' business experience causes an increase of $0.256 \%, 0.574 \%, 0.079 \%, 0.613 \%$, and $0.071 \%$ in the repayment rate, respectively. A $1 \%$ increase for the client's age will cause a $0.047 \%$ decrease for the repayment rate.

Table 6. Estimated Tobit Model for Factors Influencing loan Repayment.

\begin{tabular}{llll}
\hline Variables & Coefficient (B) & Z-value & Sig. \\
\hline Constant & 0.922 & 16.77 & 0.000 \\
Loan borrowed (X1) & 0.256 & 1.874 & 0.337 \\
Loan repaid (X2) & 0.574 & 4.954 & 0.000 \\
No. of borrowers (X3) & 0.079 & 0.559 & 0.579 \\
No. of staff members (X4) & 0.613 & 5.481 & 0.000 \\
Borrower's age (X5) & -0.047 & -0.331 & 0.742 \\
Borrower's Experience (X6) & 0.071 & 0.505 & 0.015 \\
Log Likelihood =-10424.543, & & & \\
Wald Statistic $=208.894$ & & & \\
\hline
\end{tabular}

Source: Author's Analysis

Further and as shown in Table 6, the Non-conformity of the borrowed loans to hypothesis by showing a positive relationship with repayment performance could be attributed to the explanation that higher loans is an incentive for larger investments with potentially higher returns. In other words, larger loan sizes would enhance the beneficiary client's access to basic inputs and improved management opportunities, which would lead to higher productivity, reduced cost per unit, and increased income.

This high repayment rate (average $=92 \%$ ) may be attributed to the sound lending policy adopted by LAPO which perhaps resulted in low probabilities of loan default. The positive relationship between the number of borrowers and the repayment rate could be a useful indicator of the credit agency's outreach or effective marketing. The positive sign of the coefficient is also suggestive of the opinion that the greater the number of people covered, the greater the repayment rate. The borrower's age is a very important factor in any enterprise because youths and young adults who are full of vigor are germane to efficient production. The average age of the LAPO beneficiaries was 48 years. The majority of borrowers were between 30 and 50 years old, an age in which they are considered highly productive and active to engage in work. This perhaps is the fulcrum upon which LAPO's high repayment rate was built, as most of their borrowers were able to repay and timely. Thus, LAPO should be able to consider the age of borrower when offering loans as older clients tend to exhibit high default rate in loan repayment. As with the borrower's age, borrower's experience is equally important when offering loans to beneficiaries. The average experience of LAPO beneficiaries is 20 years. This experience is reflected in the high repayment rate. Borrowers who have a lot of experience exhibit a willingness to adopt new technologies. The result is that there is higher productivity, more revenues, and higher abilities to repay loans.

The administrative performance of LAPO was largely affected by the number of staff members marketing services to customer. As shown in Table 1, LAPO has a well-trained and experienced staff. This staff constitute a major factor for the LAPO achieving its high repayment rate. A sufficiently trained staff will result in proper monitoring and supervision of the credit agencies. Insufficient staff numbers cause lack of supervision and monitoring services. Hence, clients may transfer their loan to other purposes aside what the loan is meant for. For a staff to monitor 341 borrower is on high side as monitoring could be done haphazardly. In this regards, LAPO's interest may not be jeopardized (as the result shows) but the technical advice/support supposedly to be offer to client will be hampered by excess burden on desk/supervisory officers.

\section{Conclusion}

The present study is an attempt to assess the repayment performance of the micro-credit agencies using LAPO as a case study. Hence, the study investigated some important factors related to loan repayment performance drawing from the LAPO's experience and making appropriate recommendations to inform policies. The demographical characteristics of borrowers from LAPO shows majority are illiterate with large household size and in their productive age.

The results of the analyses show that the average repayment rate of LAPO was 0.92 . This indicate a relatively high rate of repayment performance and a low default rate (0.08). This result may be attributed to many exogenous and endogenous factors. The volume of loans borrowed $\left(\mathrm{X}_{1}\right)$, the 
volume of loans repaid $\left(\mathrm{X}_{2}\right)$, the number of borrowers $\left(\mathrm{X}_{4}\right)$, and number of credit agency staff members, the borrower's age $\left(\mathrm{X}_{5}\right)$, and the borrower's experience $\left(\mathrm{X}_{6}\right)$ were the most important factors related to LAPO's repayment performance. All these factors had positive effects on the repayment performance of LAPO, except for age. The high rate of repayment when examined in the light of number of borrowers to staff ( 341 to 1 ) is not good for the borrowers as technical advice would be scanty if not denied. As the result shows, age is an important variable in terms of loan repayment is concerned. Older people tend to be inclined to defaulting in repayment. Such should be crowded out, that is the procedures for loan accessibility should be tighten up for such category of people. Controls, supervision and monitoring of loans and beneficiary need to be improved upon to keep the repayment performance at the present level. Introducing a reward system for those individuals who paid on time will be helpful in enhancing the repayment performance. Measures that de-risk loan to borrowers and sustain volume of loans borrowed, the volume of loans repaid, number of borrowers, the number of credit agency staff members at the present levels in LAPO are recommended.

\section{References}

[1] Adams, D., \& Graham, D. (1981). A critique of traditional Lift above Poverty organization projects and policies. Journal of Development Economics, 53, 153-172.

http://dx.doi.org/10.1016/0304-3878 (81)90021-3.

[2] Akinola AA, and Young T. (1985) An application of the Tobit model in the analysis of agricultural innovation adoption processes: A study of the use of cocoa spraying chemicals among Nigerian cocoa farmers. Oxford Agrarian Studies. 16: 26-51.

[3] Awoyemi, T. T and Olowa, O. W. (2010). Determination of Loan Repayment Potentials of Group Borrowers in Oyo State of Nigeria. Agricultural Journal, 5, 12-18. http://dx.doi.org/10.3923/aj.2010.12.18.

[4] Arene, C. J. (1992). Loan repayment and technical assistance among smallholder maize clients in Nigeria. African Review of Money and Banking. A Supplement of Savings and Development Journal, 1, 64-72. Retrieved from http://www.jstor.org/stable/i23027445.

[5] Copisarow, R. (2000). The application of micro credit technology to the UK: Key Commercial and Policy Issues.Journal of Microfinance, 2 (1), 13-42. Retrieved from https://ojs.lib.byu.edu/spc/index.php/ESR/issue/view/153.

[6] Coyle, B. (2000). Framework for credit risk management. CIB Publishing. London. UK.

[7] Derban, W. K., Binner, J. M., \& Mullineux, A. (2005). Loan repayment performance in community development finance institutions in the UK. Small Business Economics, 25 (4), 319332. http://dx.doi.org/10.1007/s11187-004-6483-y.

[8] Dunford, C. (1998). Microfinance: A means to what end? Monday Developments, 16; (17): 6 Retrieved on May 1, 2015 from http://www.alternative-finance.org.uk/cgibin/summary.
[9] Falaiye, C. A. (2003). Assessing the household impact of microcredit on rural Nigerian women. MSc dissertation. University of Guelph, Canada.

[10] FAO (Food and Agricultural Organization). (1996). Rural informal credit markets and the effectiveness of policy reform. Economic and social markets and social development, Rome (p. 134). Gonzalez, V. C. (1977). Interest rate restrictions and income distribution. American Journal of $\begin{array}{llll}\text { AgriculturalEconomics, } & 59 & \text { (5), } & \text { 973-976. }\end{array}$ http://dx.doi.org/10.2307/1239874.

[11] Greenbaum, S. I., \& Thakor, A. V. (1995). Contemporary financial intermediation. Forth Worth, Texas, USA: Dryden Press.

[12] Hoque, M. Z. (2000). Guided industrial credit. Monash University. Retrieved from http://www. bizresearchpapers.com/Document4.pdf.

[13] Hulme, D., \& Mosley, P. (1996). Finance against poverty. Volume 2: Country Case Studies (pp. 201-232). London, UK: Taylor \& Francis Group.

[14] Koutsyiannis, A. (2001). Correlation Theory in Theory of Econometrics (pp. 31-43). New York: Replika Press.

[15] Lift above Poverty organisation (LAPO). (2014). Annual Report: Nigeria.

[16] Mohammad, R. (2004). Some features of rural finance in the Near East and North Africa Region-Studies and Remarks (2nd ed.). Amman, Nigeria: Near East North Africa Regional Lift above Poverty organisationAssociation (NENARACA).

[17] Nannyonga, H. L. (2000). Determinants of repayment behavior in the Centenary Rural Development Bank inUganda. Doctoral Dissertation. The Ohio State University. United States. Retrieved from http://rave.ohiolink.edu/etdc/view?LAPO_num=osu12242714 32.

[18] Njoku, J. E., \& Obasi, P. C. (2001). Loan repayment AGF Lift above Poverty organisationguarantee scheme and its determinants under the (ALGS) in Imo State, Nigeria. Africa Review of Money, Finance and Banking.

[19] Nweke FI. (1996) Cassava: A cash crop in Africa. COSCA working paper No. 14, collaborative study of cassava in Africa, International Institute of Tropical Agriculture, Ibadan, Nigeria; 1996.

[20] Oke, J., Adeyemo, R., \& Agbonlahor, M. (2007). An empirical analysis of micro credit repayment in Southwestern Nigeria. Humanity and Social Sciences Journal, 2 (1), 63-74.

[21] Ozdemir, O., \& Boran, L. (2004). An empirical investigation on consumer credit default risk. Discussion Paper. 2004/20. Turkish Economic Association, Turkey. Retrieved from http://www.tek.org.tr/dosyalar/O-OZDEMIR-CREDR.pdf.

[22] Pischke, J. P. (1980). Rural credit project design, implementation and loan collection performance. Saving and Development Quarterly Review, 4 (2), 81-91.

[23] Roslan, A. H., \& Zaini, M. (2009). Determinants of micro credit repayment in Malaysia: the case of Agrobank. Humanity \& Social Sciences Journal, 4 (1), 45-52. Retrieved from http://www.idosi.org/hssj/hssj4 (1)09/6.pdf. 
[24] Shepelwich, S. C. (2003). Remedial loan associations: A historical contribution to current microfinance practice. Msc. Dissertation Abstract, Michigan State University.

[25] Stiglitz, E. J., \& Weiss, A. (1981). Credit rationing in markets with imperfect information. American Economic Review, 71, 393-410. Retrieved from http://www.jstor.org/stable/1802787
Tobin James (1958) Estimation of Relationships for Limited Dependent Variables" Econometrica, 26 (1): 24-36.

[26] Tobin James (1958) Estimation of Relationships for Limited Dependent Variables" Econometrica, 26 (1): 24-36.

[27] UN Resolution 53/197 (1998). Retrieved on June 22, 2004 from http://www.un.org/Depts/dhl/resguide/r53.htm. 